\title{
IbM KELOMPOK TANI HORTIKULTURA DALAM RANGKA PERBAIKAN MANAJEMEN PRODUKSI KOMPOS
}

\author{
Anis Sholihah ${ }^{1}$ Nurhidayati ${ }^{2}$ \\ ${ }^{1}$ Fakultas Pertanian Universitas Islam \\ email: ash unisma@yahoo.com \\ ${ }^{2}$ Fakultas Pertanian Universitas Islam Malang \\ email: nht unisma@yahoo.com
}

\begin{abstract}
Tegalweru village, Dau, Malang regency is known as a high producer of horticultural crops with a total area of horticultural crops to \pm 336 ha or $80 \%$ of the total area of agricultural land. To maintain the productivity of horticultural crops is necessary land management system with organic inputs. However, the availability of compost in this village is still inadequate. Compost production system that is not running optimally, although it has been available the tools for composting. An understanding of composting technology is still low. Specific targets to be achieved in this activity is an increase in the compost product produced from compost production systems that exist in the two farmers groups Weru Asih I and II, who became a partner in this activity. IbM activities were implemented through several stages: (1) extension of composting technology and the role of organic matter (2) the training and mentoring of making compost, (3) Building composting home, and (4) Counseling and guidance of management system of sustainable compost production. The results of this work showed that horticultural farmers at Tegalweru village already can independently make compost with a high quality. This activity greatly helped to provide compost for farmers. It is also able to improve the understanding of the members of farmer group in maintaining soil fertility. For the sustainability of this program, implementation of barter management system between compost material with mature compost can be used as an initial step in the development of commercial compost production at Tegaweru village.
\end{abstract}

Key word; rumah kompos, manajeman produksi kompos, grinder

\section{PENDAHULUAN}

Desa Tegalweru dengan luas lahan pertanian 420 ha (92\% dari total luas wilayah) merupakan wilayah potensial untuk pengembangan pertanian intensif dan didukung dengan kondisi tanah yang cukup subur akan mempercepat perkembangan pertanian di wilayah tersebut. Namun dengan pengelolaan tanpa masukan bahan organik yang memadai akan dapat menurunkan kondisi kesuburan tanah (Wolf dan Snyder, 2003).

Hasil diskusi dengan anggota kelompok tani dilaporkan bahwa proses pembuatan kompos pernah dilakukan, namun hasil kompos yang diperoleh kurang bagus. Para kelompok tani hortikutura desa Tegalweru berkeinginan untuk memahami cara pembuatan kompos yang berkualitas 
sehingga dapat memberikan dampak positif terhadap tanaman yang dibudidayakan. Permasalahan lain yang dihadapi oleh kedua kelompok tani dalam sistem produksi kompos adalah belum memiliki rumah kompos yang permanen, sehingga proses pengomposan tidak dapat dilakukan secara terus menerus. Sarana lain yang belum tersedia adalah alat pencacah kompos atau grinder yang sangat dibutuhkan untuk produksi kompos. Masalah lain yang dihadapi adalah sistem manajemen produksi kompos, terutama terkait dengan proses penyediaan bahan. Pengangkutan bahan kompos dari lokasi kandang sering menjadi kendala. Oleh karena itu perlu adanya manajemen penyediaan bahan yang tepat yang dapat menguntungkan kedua belah pihak.

Limbah peternakan dan limbah pertanian yang dihasilkan dari hasil kegiatan usaha tani masyarakat desa Tegalweru merupakan sumber potensial bahan baku pupuk organik. Namun demikian secara umum masyarakat masih menangani limbah secara sederhana yaitu menumpuknya (Gambar 1) limbah-limbah tersebut sehingga memungkinkan terjadinya proses pematangan (pengomposan) secara alami yang memerlukan waktu cukup lama.

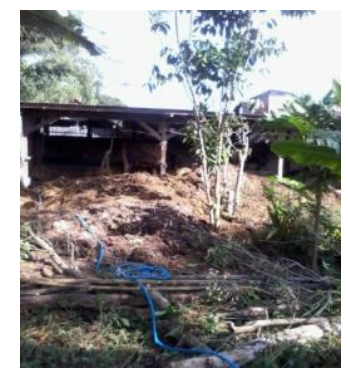

Gambar 1. Kotoran Sapi Dan Limbah Pertanian Yang Menumpuk

Di Dekat Kandang Sapi

\section{KAJIAN LITERATUR}

Bahan organik memiliki peranan penting sebagai sumber karbon dan sumber energi untuk mendukung kehidupan dan berkembangbiaknya berbagai jenis mikroba tanah (Sisworo, 2006). Penurunan kandungan bahan organik tanah menyebabkan mikroba dalam tanah mengalami defisiensi karbon sebagai sumber makanannya sehingga perkembangan populasi dan aktivitasnya terhambat. Hal ini mengakibatkan proses mineralisasi hara menjadi unsur yang tersedia bagi tanaman akan terhambat. Bahan organik juga berperan penting dalam proses aggregasi tanah untuk membentuk struktur tanah yang baik dengan konsistensi gembur, sehingga kecepatan infiltrasi air dan ketersediaan air tanah meningkat. Selain itu bahan organik dapat meningkatkan kapasitas tanah menahan air dan hara yang bermanfaat dalam proses penyediaan hara secara bertahap selama siklus pertumbuhan tnaman (Havlin et al., 2005). Oleh karena itu mempertahankan kandungan bahan organik tanah sangat 
penting untuk memperbaiki kesuburan dan kualitas tanah (Hairiah et al., 2005; Leifeld dan Kögel-Knabner, 2005).

Desa Tegalweru adalah salah satu desa binaan Fakultas Pertanian Unisma, yang terletak di Kecamatan Dau, Kabupaten Malang, dan berada pada ketinggian antara $600-700 \mathrm{~m}$ dpl, dengan luas wilayah sebesar 455,79 ha, dimana $\pm 77 \%$ bentang lahannya berupa perbukitan. Dari luas wilayah tersebut $56 \%$ berupa lahan tegal (lahan kering), 5,5\% lahan sawah tadah hujan, 5,2 \% lahan sawah setengah teknis, 25,23\% perkebunan. Tingkat kesuburan tanahnya termasuk kategori sedang, Berdasarkan kondisi lingkungan fisik tersebut, desa Tegalweru berpotensi sebagai lahan pertanian intensif (Profil Desa, 2012).

Desa Tegalweru terletak tidak jauh dari wilayah perkotaan, kurang lebih berjarak $7 \mathrm{~km}$ dari kampus Universitas Islam Malang. Selain itu desa Tegalweru bersebelahan dengan desa Merjosari yang memiliki pasar cukup besar dan beberapa kompleks perumahan. Dengan demikian kondisi desa Tegalweru cukup ramai, yang sangat mendukung untuk peningkatan kondisi perekonomiannya.

\section{METODE KEGIATAN}

Program pengabdian kepada masyarakat ( $\mathrm{lbm})$ ini dalam bentuk penyuluhan, pelatihan, pendampingan dan penyediaan sarana dan prasana yang meliputi beberapa tahapan sebagai berikut :

1. Sosialisasi kepada para petani di desa Tegalweru melalui kepala Desa khususnya dusun Jengglong dan Krajan tentang pelaksanaan kegiatan ini.

2. Pengadaan rumah kompos di salah satu lahan milik petani dan pengadaan alat pencacah.

3. Penyuluhan tentang teknologi pembuatan kompos dan pupuk organik.

4. Praktek pembuatan kompos

5. Pelatihan dan pendampingan sistem manajemen produksi kompos

6. Pengamatan keberhasilan program

\section{HASIL DAN PEMBAHASAN}

\section{HASIL}

\section{Sosialisasi Kepada Para Petani Di Desa Tegalweru}

Sosialisasi dilaksanakan dengan tujuan memberikan gambaran kepada petani di dusun Jengglong dan Krajan tentang pelaksanaan program. Sosialisasi masih terbatas pada kepala desa dan ketua kelompok tani di masing-masing dusun selanjutnya hasil sosialisasi diteruskan pada masing-masing anggota kelompok tani. Salah satu hasil sosialisasi yang penting dicapainya kesepakatan lokasi pembuatan rumah kompos, persiapan bahan-bahan kompos yang dibutuhkan dan pelaksanaan kegiatan penyuluhan. Pembangunan rumah kompos dilakukan di salah satu lahan milik petani yang dekat dengan kandang sapi. Sealanjutnya 
dicapai pula pelaksanaan penyuluhan tentang teknologi pembuatan kompos dan pupuk organik, praktek pembuatan kompos serta penyuluhan dan pendampingan manajemen produski kompos.

\section{Pembangunan Rumah Kompos}

Pembangunan rumah kompos mempunyai beberapa tujuan yaitu (1). memberikan tempat pembuatan kompos yang memang sangat dibutuhkan oleh masyarakat di desa Tegalweru, (2).Pengomposan dapat dilakukan secara terus menerus karena sudah terdapat tempat yang layak untuk produksi kompos, (3) mempermudah sistem manajemen produksi kompos, terutama terkait dengan proses penyediaan bahan.

Lokasi pembangunan rumah kompos milik petani terletak di dusun Krajan tepatnya di dekat kandang sapi untuk mempermudah pengambilan bahan-bahan kompos (kotoran sapi). Luas rumah kompos sendiri adalah 3 x $4 \mathrm{~m}^{2}$. Proses awal pembuatan rumah kompos terlihat pada Gambar 2 dan rumah kompos setengah jadi dan jadi terlihat pada Gambar 3.

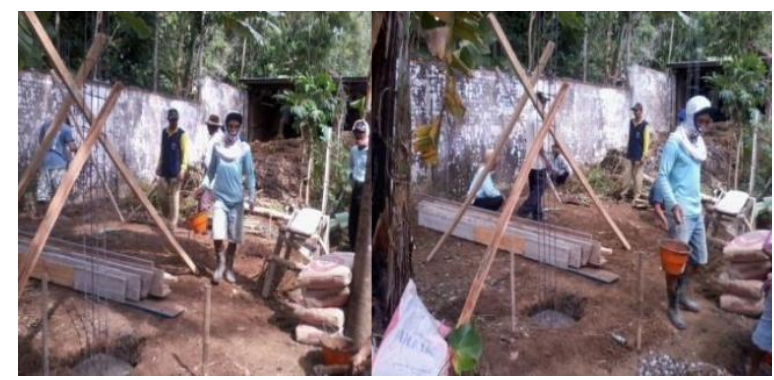

Gambar 2. Proses awal pembangunan rumah kompos

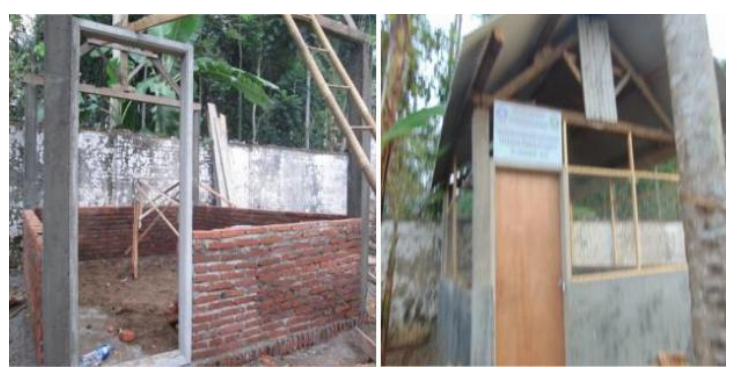

Gambar 3.Rumah Kompos Jadi Dan Setengah Jadi

\section{Pengadaan alat Grinder Kompos}

Grinder kompos berfungsi menghaluskan bahan-bahan kompos. Pengadaan grinder kompos bertujuan untuk mempermudah proses produksi kompos di desa Tegalweru yang memang belum mempunyai alat tersebut. Adanya grinder kompos diharapkan produksi kompos dapat berlangsung cepat dan terus menerus sehingga kebutuhan kompos di desa Tegalweru dapat dipenuhi dan bahkan dapat dijual kepada desa- 
desa lain disekitarnya sehingga dapat menambah pengahasilan petani desa Tegalweru.

Grinder kompos (Gambar 4) yang dimaksud mempunyai spesifikasi bahan terbuat dari besi, penggerak 7 PK dan Dimensi $115 \times 100 \times 125 \mathrm{~cm}$ dengan kapasitas 200-300 Kg/jam.

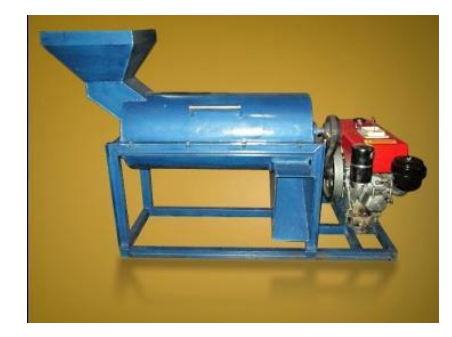

Gambar 4. Alat Grinder Kompos

Selain grinder pembuatan kompos memerlukan alat-alat bantu yang lain untuk mempercepat proses pembuatan kompos yaitu; sprayer, cetok, terpal/plastic, drum plastic dan thermometer.

\section{Penyuluhan Tentang Teknologi Pembuatan Kompos Dan Pupuk Organik}

Pelaksanaan penyuluhan dilakukan sebelum praktek pembuatan kompos dengan tujuan memberikan pemahaman kepada petani tentang pentingnya pupuk kompos dalam mempertahankan kesuburan tanah. Pelaksanaan penyuluhan diikuti kurang lebih 30 petani. Materi penyuluhan terdiri dari dari yaitu; 1.) Peranan pupuk organic/kompos bagi kesuburan tanah dan materi yang kedua 2). Teknologi pembuatan kompos. Selanjutnya besok harinya dilanjutkan dengan praktek pembuatan kompos. Kegiatan penyuluhan berjalan lancar dan petani antusias sekali terlihat dari diskusi yang terjadi yaitu adanya respon yang sangat bagus dari petani yang hadir. Pelaksanaan penyuluhan (Gambar 5).

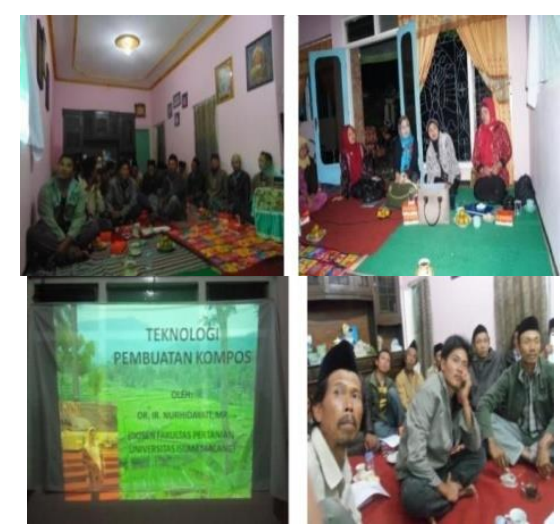

Gambar 5. Penyuluhan Teknologi Pembuatan Kompos 


\section{Praktek Pembuatan Kompos}

Sebelum praktek pembuatan kompos bahan-bahan kompos perlu disiapkan sebelumnya berapapun jumlahnya tidak menjadi masalah, makin banyak bahan -bahan kompos yang disiapkan oleh petani makin banyak produksi kompos yang dihasilkan. Bahan-bahan kompos disiapkan sendiri oleh petani dengan mengumpulkan bahan-bahan yang ada di sekitar daerah mereka sendiri. Bahan -bahan yang dimaksud adalah ; kotoran sapi, seresah-seresah tumbuhan, limbah pertanian, EM-4 dan bahanbahan mikroorganisme local.

Pelatihan pembuatan kompos dilakukan di rumah kompos yang telah dibangun diikuti oleh anggota kelompok tani. Kegiatan pembuatan kompos dilakukan melalui beberapa tahapan sehingga diperoleh kompos yang sudah matang dan siap diaplikasikan ke lahan pertanian.Tahapan-tahapan pelaksanaan pembuatan kompos sebagai berikut:

a. Persiapan bahan-bahan kompos berupa serasah atau biomas tanaman dan limbah kotoran ternak yang telah disiapkan sendiri oleh petani sehari sebelum pelaksanaan praktek.

b. Persiapan alat pencacah/grinder dengan jalan pemberian bahan bakar dan pengecekan alat grinder dengan tujuan memastikan mesin dapat bekerja dengan baik. (Gambar 6)

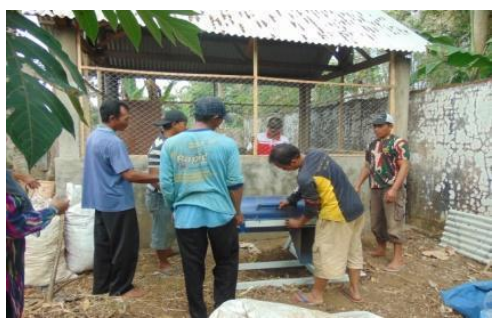

Gambar 6. Pengecekan Grinder

c. Pencacahan bahan kompos dengan mesin grinder untuk mendapatkan ukuran bahan kompos yang lebih kecil dan seragam sehingga dapat mempercepat proses dekomposisi bahan organic.(Gambar 7).

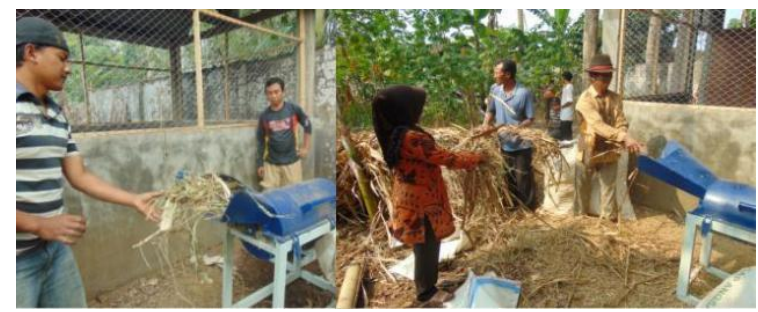

Gambar 7. Pencacahan Bahan Kompos Dengan Mesin Grinder 
d. Pengenceran starter mikroorganisme berupa EM-4 dengan takaran disesuaikan dengan volume bahan kompos.

e. Penyiraman bahan kompos dengan air yang diikuti dengan pemberian starter mikroorganisme untuk mendapatkan kelembaban optimum untuk proses pengomposan (50-60\%) yang secara fisik ditandai jika diremas terasa basah tetapi air tidak sampai menetes. Bahan kompos yang terlalu basah (> 60\%) dapat mengakibatkan bau tidak sedap dan aktvitas mikroba menurun sementara jika terlalu kering $(<40 \%)$ aktivitas mikroba juga menurun. Bahan kompos terdiri atas campuran limbah kotoran ternak sapi, biomas tanaman tebu, limbah jagung dan jerami padi.

f. Penumpukan dan penutupan bahan kompos dilakukan setelah bahan telah tercampur rata dilakukan penumpukan dan pengaturan dengan lebar dan tinggi sekitar 1 meter dan panjang 2 meter diikuti dengan penutupan menggunakan terpal plastik supaya proses fermentasi dapat berjalan optimum. Untuk memberikan sirkulasi udara yang baik diberi paralon sebagai jalan aliran udara menjadi lancer.(Gambar 8).

g. Pengontrolan proses pengomposan dilakukan dengan mengukur suhu pada tumpukan bahan kompos dimulai sekitar 5- 7 hari setelah pemrosesan bahan kompos. Tujuan pengukuran suhu untuk menjaga suhu pada kisaran optimum untuk proses fermentasi oleh mikroorganisme. Jika suhu tumpukan

bahan kompos terlalu tinggi mencapai $>60-70^{\circ} \mathrm{C}$ perlu dilakukan pembasahan dengan penyiraman disertai pembalikan tumpukan bahan kompos sebaliknya apabila suhu terlalu rendah dilakukan pembongkaran dengan membuka terpal plastic beberapa jam atau 1-2 hari sampai kondisi optimum.(Gambar 9)

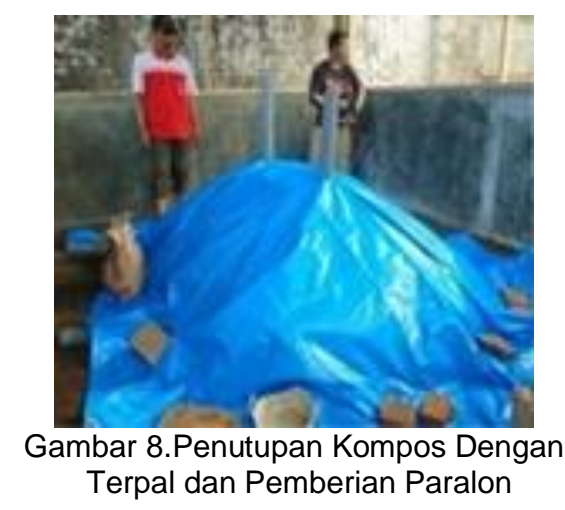




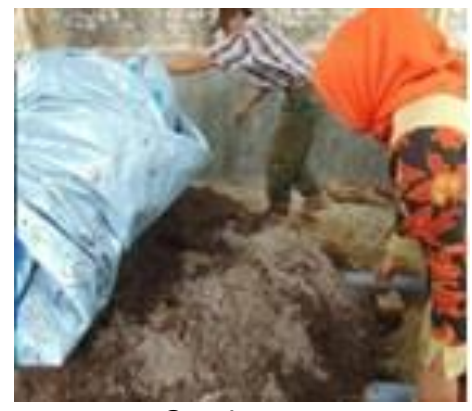

Gambar

9.Pembongkaran Kompos

h. Kompos matang

Pemanenan kompos dilakukan pada saat kompos telah matang sekitar umur empat minggu. Kompos yang sudah matang secara fisik ditandai warna coklat kehitaman, tekstur remah dan tidak berbau.

\section{Penyuluhan Dan Pendampingan Sistem Manajemen Produksi Kompos}

Penyuluhan dan pendampingan tentang analisis ekonomi produksi kompos dengan sistem barter bahan baku dengan kompos yang telah jadi. Mekanisme kegiatan ini dilakukan dengan cara pendataan petani yang memiliki dan yang tidak memiliki ternak sapi. Petani yang memliki ternak sapi menyetor kotoran sapi sedang yang tidak memiliki ternak sapi menyetor limbah pertanian selanjutnya bahan-bahan baku kompos tersebut ditukar dengan kompos yang telah matang Dengan cara seperti ini diharapkan proses produksi kompos dapat berlangsung terus.

\section{Pengamatan Keberhasilan Program}

Keberhasilan program IbM ini terlihat sangat signifikan dampaknya kepada petani di desa Tegalweru. Pengamatan keberhasilan program dilakukan dengan penyebaran kuisener yang disebar pada seluruh anggota kelompok tani Weru Asih I dan II.

\section{PEMBAHASAN}

Masyarakat Desa Tegalweru didominasi usaha tani budidaya tanaman jeruk selain itu juga peternakan dengan memelihara sapi dengan rata- rata kpemilikan 2 - 5 ekor perkeluarga. Permasalahan yang dihadapi adalah limbah pertanian dan kotoran ternak yang melimpah, mereka hanya menimbunnya di pekarangan sekitar rumah sehingga dapat menyebabkan pencemaran udara berupa bau yang tidak sedap serta memungkinkan pencemaran terhadap sumber air. Pada kondisi alami limbah organik yang ada dipermukaan tanah dengan temperatur permukaan normal dan kondisi aerob akan terdekomposisi secara lambat. Dengan demikian diperlukan 
upaya atau tindakan pengomposan secara buatan agar diperoleh kompos yang proses pematangan lebih cepat dan mengurangi pencemaran udara dan sumber air. Proses pembuatan kompos secara buatan membutuhkan sarana dan prasarana baik bangunan yang menetap, peralatan serta bahan-bahan penunjang proses pengomposan.

Kegiatan IbM pembangunan demplot rumah kompos serta pelatihan dan pedampingan pembuatan kompos meningkatkan kesadaran dan kemauan masyarakat untuk mengolah limbah yang selama ini dibiarkan tertimbun di pekarangan rumah dengan mencampurnya dengan limbah biomas tanaman termasuk jerami padi, jagung, tebu sebagai hasil samping panenan (setelah tercukupi kebutuhan untuk pakan ternak) untuk menghasilkan pupuk organik sehingga dapat mengurangi biaya untuk pembelian pupuk organik. Pengetahuan dan ketrampilan masyarakat dalam proses pembuatan kompos juga harus didukung pengetahuan tentang kualitas bahan kompos yang dapat mempengaruhi kualitas kompos terutama komposisi unsur haranya. Pengetahuan akan komposisi unsur hara dalam kompos sangat berpengaruh dalam menentukan dosis penggunaannya di lapangan.

Kualitas kompos (kandungan unsur hara) ditentukan oleh komposisi bahan baku yang digunakan untuk pembuatan kompos. Kandungan unsur hara $(\mathrm{N}, \mathrm{P}, \mathrm{K})$ limbah kotoran ternak sangat beragam ditentukan oleh jenis ternak serta pakan dan tempat hidupnya. Serasah atau biomasa tanaman juga memiliki kandungan unsur hara yang berbeda. Tanaman jenis legum (kacang-kacangan) memiliki kandungan $\mathrm{N}$ cukup tinggi sehingga lebih cepat terdekomposisi atau menjadi kompos disamping menghasilkan kompos dengan kandungan $\mathrm{N}$ yang cukup tinggi sementara jerami padi memiliki kandungan $\mathrm{K}$ yang cukup tinggi. Hasil analisa kompos di desa Tegalweru diperoleh kompos berkualitas dengan komposisi rata-rata kandungan unsur $\mathrm{N} 0,5-1,12 \%$, P tersedia 1,13-1,97 ppm dan $\mathrm{K} 0,12-$ $0,75 \mathrm{meq} / 100 \mathrm{~g}, \mathrm{C} / \mathrm{N}$ rasio antara 10 sampai 14 , polifenol 17,05 - 29,26 \%, Lignin 13,54 - 23,78\% dan selulose 16,44 - 37,06\% Penyuluhan dan pendampingan tentang produksi kompos dengan sistem barter bahan baku dengan kompos yang telah jadi diharapkan akan dapat mengatasi permasalahan produksi kompos di desa Tegalweru apalagi didukung dengan sarana dan prasarana (rumah kompos dan alat grinder). Di desa Tegalweru terdapat 10 orang peternak sapi dan sekaligus petani jeruk selain itu 8 orang yang hanya petani saja. Untuk menjaga keberlanjutan produksi kompos petani dibagi menjadi 4 kelompok, masing-masing kelompok secara bergiliran melaksanakan proses produksi dan bertanggungjawab sampai kompos matang dan pengemasan.

Hasil evaluasi keberhasilan program melalui penyebaran kuisioner dimana seluruh anggota kelompos tani yang menjadi rensponden $100 \%$ menyatakan sangat bermanfaat dengan adanya program ini. $100 \%$ anggota kelompok tani telah memahami cara pembuatan kompos yang 
berkualitas. Namun kemungkinan untuk pengembangan secara komersial $30 \%$ masih ragu-ragu dengan alasan tenaga kerja yang tersedia relatif sedikit dan kebutuhan kompos untuk lahan pertanian di wilayah Desa Tegalweru masih belum mencukupi. Namun $70 \%$ menyatakan bahwa mereka siap mengembangkannya secara komersial dengan alasan ketersediaan bahan baku kompos melimpah di Desa Tegalweru. Solusi yang ditawarkan oleh pengabdi adalah dengan sistem manajemen barter artinya petani yang memliki ternak sapi menyetor kotoran sapi sedang yang tidak memiliki ternak sapi menyetor limbah pertanian selanjutnya bahan-bahan baku kompos tersebut ditukar dengan kompos yang telah matang. Namun untuk pengembangan secara komersial, sistem produksi kompos ini tetap membutuhkan tenaga kerja permanent yang setiap hari terlibat langsung dalam proses penyediaan, dan penerimaan bahan dari petani, proses penggilingan bahan dan proses pengomposannya serta pengemasannya. Hasil secara keseluruhan disajikan dalam Tabel 1 berikut ini;

Tabel 1.

Indikator Pelaksanaan Program

\begin{tabular}{|l|l|l|c|}
\hline \multicolumn{1}{|c|}{ Indikator } & Base line & $\begin{array}{c}\text { Capaian setelah } \\
\text { Program berlangsung }\end{array}$ & $\begin{array}{c}\text { Pening } \\
\text { katan }\end{array}$ \\
\hline $\begin{array}{l}\text { Ketersediaan } \\
\text { Alat Pencacah } \\
\text { dan } \\
\text { penghancur } \\
\text { bahan kompos }\end{array}$ & $\begin{array}{l}0 \% \\
\text { (belum } \\
\text { tersedia) }\end{array}$ & $\begin{array}{l}\text { Tersedia 1 alat pencacah } \\
\text { dan penghancur bahan } \\
\text { kompos }\end{array}$ & $100 \%$ \\
\hline $\begin{array}{l}\text { Ketersediaan } \\
\text { Rumah } \\
\text { kompos }\end{array}$ & $\begin{array}{l}0 \% \\
\text { (belum } \\
\text { teredia) }\end{array}$ & $\begin{array}{l}\text { Tersedia 1 rumah } \\
\text { kompos untuk 2 } \\
\text { kelompok tani }\end{array}$ & $50 \%$ \\
\hline $\begin{array}{l}\text { Jumlah } \\
\text { anggota } \\
\text { kelompok tani } \\
\text { yang } \\
\text { memahami } \\
\text { proses } \\
\text { pembuatan } \\
\text { kompos }\end{array}$ & $\begin{array}{l}25 \% \\
\text { anggota } \\
\text { kelompok } \\
\text { tani dapat } \\
\text { membuat } \\
\text { kompos }\end{array}$ & $\begin{array}{l}100 \% \text { anggota } \\
\text { kelompok tani telah } \\
\text { memahami cara } \\
\text { pembuatan kompos } \\
\text { yang berkualitas }\end{array}$ & $75 \%$ \\
\hline $\begin{array}{l}\text { Ketersediaan } \\
\text { kompos }\end{array}$ & $\begin{array}{l}0 \% \\
\text { (belum } \\
\text { tersedia } \\
\text { secara } \\
\text { lokal) }\end{array}$ & $\begin{array}{l}\text { tersedia kompos untuk } 2 \\
\text { kelompok tani sebesar } \\
\text { kompos }\end{array}$ & $50 \%$ \\
\hline $\begin{array}{l}\text { Kemungkinan } \\
\text { pengembangan } \\
\text { secara } \\
\text { komersial }\end{array}$ & $0 \%$ & $\begin{array}{l}70 \% \text { anggota kelompok } \\
\text { tani menyatakan } \\
\text { sanggup untuk } \\
\text { mengembangkan secara } \\
\text { komesial }\end{array}$ & $70 \%$ \\
\hline
\end{tabular}




\section{KESIMPULAN}

Kegiatan pengabdian pada kelompok tani hortikultura di Desa Tegalweru dengan topic pembuatan kompos yang berkualitas sangat dibutuhkan untuk meningkatkan pengetahuan petani dalam proses pembuatan kompos dan manajemen produksinya dalam upaya menerapkan sistem pertanian berkelanjutan dalam budidaya tanaman hortikultura. Pengadaan alat pencacah dan penghancur bahan kompos serta pembangunan rumah kompos secara berkelanjutan sangat membantu penyediaan kompos secara berbagi petani hortikultura di Desa Tegalweru.

\section{REFERENSI}

Hairiah , K., van Noordwijk, M., and Weise, S. 2005. Sustainability of Tropical Land Use Systems After Forest Conversion . Columbia Univ. Press., New York. p. 143-170.

Havlin, J.L,J.D.Beaton, A.L.Tisdale and W.L. Nelson. 2005. Soil Fertility and Fertilizers. $7^{\text {th }}$ edition. Pearson Prentice Hall. Upper Saddle River, New Jersey.

Leifeld, J., and Kögel-Knabner, I. 2005. Soil organic matter fractions as early indicators for carbon C-org changes under different land-use. Geoderma 124: 143-155.

Sisworo, W.H., 2006. Swasembada Pangan dan Pertanian Berkelanjutan. Tantangan Abad Dua Satu : Pendekatan IImu Tanah, tanaman dan Pemanfataan Iptek Nuklir. Dalam A. Hanafiah WS, Mugiono,dan E.L. Sisworo. Badan Tenaga Nuklir Nasional, Jakarta. 207 hal.

Wolf, B and Snyder, G.H. 2003. Sustainable Soils : The Place of Organic Matter in Sustaining Soils and Their Productivity. Food Product Press. An Imprint of The Haworth Press. Inc. New York. P. 105 - 246 